Françoise Auchère $\cdot$ Robert Sikkink $\cdot$ Cristina Cordas Patricia Raleiras · Pedro Tavares · Isabel Moura

José J. G. Moura

\title{
Overexpression and purification of Treponema pallidum rubredoxin; kinetic evidence for a superoxide-mediated electron transfer with the superoxide reductase neelaredoxin
}

Received: 9 June 2004 / Accepted: 22 July 2004 / Published online: 20 August 2004 (C) SBIC 2004

\begin{abstract}
Superoxide reductases are a class of non-haem iron enzymes which catalyse the monovalent reduction of the superoxide anion $\mathrm{O}_{2}^{-}$into hydrogen peroxide and water. Treponema pallidum (Tp), the syphilis spirochete, expresses the gene for a superoxide reductase called neelaredoxin, having the iron protein rubredoxin as the putative electron donor necessary to complete the catalytic cycle. In this work, we present the first cloning, overexpression in Escherichia coli and purification of the Tp rubredoxin. Spectroscopic characterization of this $6 \mathrm{kDa}$ protein allowed us to calculate the molar absorption coefficient of the $490 \mathrm{~nm}$ feature of ferric iron, $\varepsilon=6.9 \pm 0.4 \mathrm{mM}^{-1} \mathrm{~cm}^{-1}$. Moreover, the midpoint potential of $\mathrm{Tp}$ rubredoxin, determined using a glassy carbon electrode, was $-76 \pm 5 \mathrm{mV}$. Reduced rubredoxin can be efficiently reoxidized upon addition of $\mathrm{Na}_{2} \mathrm{IrCl}_{6}$ oxidized neelaredoxin, in agreement with a direct electron transfer between the two proteins, with a stoichiometry of the electron transfer reaction of one molecule of oxidized rubredoxin per one molecule of neelaredoxin. In addition, in presence of a steady-state concentration of superoxide anion, the physiological substrate of neelaredoxin, reoxidation of rubredoxin was also observed in presence of catalytic amounts of superoxide reductase, and the rate of rubredoxin reoxidation was shown to be proportional to the concentration of neelaredoxin, in agreement with a bimolecular
\end{abstract}

F. Auchère $\cdot$ C. Cordas $\cdot$ P. Raleiras $\cdot$ P. Tavares $\cdot$ I. Moura J. J. G. Moura $(\square)$

REQUIMTE - Centro de Química Fina e Biotecnologia, Departamento de Química, Faculdade

de Ciências e Tecnologia, Universidade Nova de Lisboa, 2829-516 Caparica, Portugal

E-mail: jose.moura@dq.fct.unl.pt

Tel.: + 351-21-2948382

Fax: + 351-21-2948550

R. Sikkink

Department of Biochemistry and Molecular Biology,

Section of Hematology Research,

Mayo Clinic, Rochester, MN 55905, USA reaction, with a calculated $k_{\mathrm{app}}=180 \mathrm{~min}^{-1}$. Interestingly, similar experiments performed with a rubredoxin from the sulfate-reducing bacteria Desulfovibrio vulgaris resulted in a much lower value of $k_{\text {app }}=4.5 \mathrm{~min}^{-1}$. Altogether, these results demonstrated the existence for a superoxide-mediated electron transfer between rubredoxin and neelaredoxin and confirmed the physiological character of this electron transfer reaction.

Keywords Electron transfer - Neelaredoxin . Rubredoxin - Superoxide reductase . Treponema pallidum

Abbreviations DEAE: diethylaminoethyl $\cdot$ Dg: Desulfovibrio gigas - Dv: Desulfovibrio vulgaris - LB: Luria-Bertani · Nlr: neelaredoxin - Rd: rubredoxin · ROS: reactive oxygen species - SOD: superoxide dismutase - SOR: superoxide reductase - TCA: trichloroacetic acid - Tp: Treponema pallidum - TPTZ: 2,4,6-tripyridyl-5-triazine

\section{Introduction}

Treponema pallidum (Tp), the syphilis spirochete, is currently classified as a microaerophile because of its limited tolerance to oxygen during in vitro cultivation, but its propagation in vivo implicates an exposure to well-oxygenated tissues [1, 2]. However, analysis of the full genome indicates that $\mathrm{Tp}$ lacks the classic antioxidant defense enzymes such as superoxide dismutase (SOD), catalase or peroxidases [3]. It was only recently reported that $\mathrm{Tp}$ presents an alternative way to survive upon transient exposure to oxygen and a reactive oxygen species (ROS) in the environment, by expressing the gene for a superoxide reductase (TP0823) [4, 5, 6]. Superoxide reductases (SORs), a new class of non-heme iron enzymes initially found in sulfate-reducing bacteria, play a fundamental role in the defense of microorganisms 
against oxidative stress, by catalyzing the monovalent reduction of the superoxide anion, rather than the dismutation, according to Eq. $1[4,5,6,7,8,9,10,11,12]$ :

$\mathrm{O}_{2}^{--}+2 \mathrm{H}^{+}+\mathrm{e}^{-} \rightarrow \mathrm{H}_{2} \mathrm{O}_{2}$

Enzymes in this family share a conserved domain of 100 amino acids accommodating a single active site Fe ion coordinated by four equatorial histidine nitrogen atoms (three $\varepsilon$ and one $\delta$ ) and an axial cysteinyl sulfur atom $[8,11,13,14,15]$. Only the reduced colorless ferrous form of the active site iron is able to react with superoxide, with a virtually diffusion controlled rate of $10^{9} \mathrm{M}^{-1} \mathrm{~s}^{-1}$, leading to the formation of the blue ferric state of the enzyme, which suggests the existence of an electron donor to regenerate the ferrous active form and complete the catalytic cycle of the enzyme $[6,16,17,18]$. The in vivo electron donor to SOR has generally not been established but previous work has strongly suggested that a rubredoxin ( $\mathrm{Rd}$ ) could be the proximal electron donor to superoxide reductases during periods of oxidative stress $[7,8,19,20,21]$.

Rubredoxins, previously isolated from Clostridium pasteurianum [22], are small soluble iron-sulfur proteins (45-54 amino acids), which feature an iron atom coordinated in a tetrahedral geometry to the four cysteinyl sulfur atoms of four conserved cysteine residues, with a common motif of two pairs of Cys-XX-Cys and a molecular weight ranging from 5000 to $6000 \mathrm{Da}[22,23$, $24,25,26]$. Rubredoxins have been found in varieties of anaerobic and aerobic bacteria and archea, and studied as models for iron-sulfur clusters, so their structures and spectroscopic features have been well described [27]. Surprisingly enough, their physiological relevance is not well understood, although they have generally been assumed to serve as electron carriers. The best-documented example is that of rubredoxin from Pseudomonas oleoverans, which is involved as an electron carrier in alkane hydroxylation [28, 29]. Rubredoxin has also been reported to be an effective electron donor to a nitrate reducing activity reconstituted in vitro for Clostridium perfringens [30].

In anaerobes, the genes encoding rubredoxin very often occur in the same operon or cluster than superoxide reductases, the gene for SOR usually being located some base pairs downstream of the gene encoding $\mathrm{Rd}$ $[10,31,32,33,34]$, and transcriptional units encoding both genes have even been demonstrated [19, 31, 33]. Moreover, an oxidoreductase activity of rubredoxins was described in Desulfovibrio gigas $(\mathrm{Dg})$ and Desulfovibrio vulgaris (Dv) $[8,35]$ and the rubredoxin-like $\mathrm{N}$-terminal domain of the superoxide reductase desulfoferredoxin from Dv has been proposed to serve as an electron donor to the active site of the enzyme [9]. However, no detailed kinetic data for the electron transfer steps of the physiological reactions involving these proteins are available, and no redox partners were conclusively identified. Only recently, the first kinetic data showing an electron transfer from rubredoxin to
Dv superoxide reductase have been published, using an NADPH superoxide oxidoreductase artificial cycle [20, 21].

In this work, we report the first cloning, overexpression in Escherichia coli and purification of the recombinant $\mathrm{Tp}$ rubredoxin. After spectroscopic and electrochemical characterization of the protein, we present detailed kinetic evidence for a superoxide-mediated electron transfer to the superoxide reductase neelaredoxin (Nlr).

\section{Materials and methods}

\section{Chemicals}

Bovine $\mathrm{Cu}, \mathrm{Zn}$ superoxide dismutase, bovine milk xanthine oxidase, xanthine, horse heart cytochrome $c$, Luria-Bertani (LB) medium, ampicillin and isopropyl- $\beta$ D-thiogalactopyranoside (IPTG) were purchased from Sigma (St Louis, Mo., USA). Sodium dithionite $\left(\mathrm{Na}_{2} \mathrm{~S}_{2} \mathrm{O}_{4}\right)$, ferrous sulfate $\left(\mathrm{FeSO}_{4}\right)$, trichloroacetic acid and sodium hexachloroiridate $\left(\mathrm{Na}_{2} \mathrm{IrCl}_{6}\right)$ were obtained from Aldrich. All buffer salts were from Merck (Mannheim, Germany). Reagents and buffers were of the highest grade commercially available and all experiments were carried out at $20^{\circ} \mathrm{C}$.

\section{Spectroscopic measurements}

Absorbance spectra, repetitive scans and kinetic absorbance measurements were performed at $20{ }^{\circ} \mathrm{C}$ with a Hewlett Packard Diode Array 8452 A spectrophotometer, interfaced with a computer allowing the collection of data. Manipulation and analysis of data were then performed using the Kaleidagraph 3.5 software. EPR spectra were recorded in a Bruker ESP 300 E spectrometer equipped with an Oxford Instruments continuous flow cryostat.

\section{Electrochemical measurements}

The potentiodynamic measurements were performed with a Potentiostat/Galvanostat AUTOLAB PGSTAT 12. Glassy carbon (GC) was the working electrode with an area of $0.06 \mathrm{~cm}^{2}$. The protein was immobilized on the electrode using a cellulose membrane (Spectra/Por membrane) with a $3500 \mathrm{Da}$ cut-off that was fitted to the electrode by an O-ring. The supporting electrolyte was $10 \mathrm{mM}$ Tris- $\mathrm{HCl}$ buffer, $0.1 \mathrm{M} \mathrm{KNO}_{3}, 2 \mathrm{mM}$ neomycin and $20 \mathrm{mM} \mathrm{MgCl}_{2}$. The protein concentration was $250 \mu \mathrm{M}$.

\section{Cloning of the $\mathrm{Tp}$ rubredoxin gene}

The E. coli based expression system used to produce rubredoxin from $\mathrm{Tp}$ was developed in the laboratory of 
Prof. Brian Volkman (Medical College of Wisconsin, USA). PCR was used to amplify a fragment of genomic DNA coding for rubredoxin with Bam HI and HindIII sites at the $5^{\prime}$ and $3^{\prime}$ ends, respectively, to facilitate insertion into a modified pQE30 vector (Qiagen, Valencia, Calif., USA). This pQE30T-Ce5073(1-120) construct simply includes an N-terminal $6 \mathrm{His}$-tag for $\mathrm{Ni}$ NTA affinity, and was subsequently used for protein overexpression in E. coli. The target protein can be separated from the fusion tag by cleavage with TEV protease also produced in the laboratory of Prof. Volkman. The choice of this His-tag construct was made after trying different overexpression strategies, as the one giving the best protein expression levels. Moreover, we were interested in the production of an His-tag rubredoxin in the laboratory, in view of future labeling experiments.

Overexpression and purification of recombinant $\mathrm{Tp}$ rubredoxin (TpRub-6His-tag fusion protein)

Competent E. coli BL21(DE3) cells (Novagen, Madison, Wis., USA) were transformed with the plasmid pQE30T-Ce5073(1-120) and plated onto LB agar plates containing ampicillin $(0.1 \mathrm{mg} / \mathrm{mL})$, after which a colony was used to inoculate $10 \mathrm{~mL}$ of LB medium containing ampicillin $(0.1 \mathrm{mg} / \mathrm{mL})$. This culture was grown at $37^{\circ} \mathrm{C}$ overnight; the next morning, it was used to inoculate $1.5 \mathrm{~L}$ of $\mathrm{LB}$ medium containing $0.1 \mathrm{mg} / \mathrm{mL}$ ampicillin in a 6-L Erlenmeyer flask. This culture was grown, with shaking, until the absorbance of the culture at $595 \mathrm{~nm}$ reached $\sim 1$. At this point, IPTG was added to a final concentration of $1 \mathrm{mM}$ to induce the expression of the protein. After an additional $7 \mathrm{~h}$ growth, the cells were harvested by centrifugation for $30 \mathrm{~min}$ at $2500 \times \mathrm{g}$ at $4{ }^{\circ} \mathrm{C}$. The cell pellet was suspended $(2.5 \mathrm{vol} / \mathrm{g}$ wet cell pellet $)$ in $50 \mathrm{mM}$ Tris- $\mathrm{HCl}(\mathrm{pH} 7.8)$ containing $0.5 \mathrm{M} \mathrm{NaCl}$ and $10 \mathrm{U} /$ $\mathrm{mL}$ Dnase, and then lysed by three passages through a French pressure cell operating at 15,000 p.s.i. at the orifice. The resulting cell lysate was then centrifuged for $30 \mathrm{~min}$ at $20,000 \times \mathrm{g}$ to remove unbroken cells and cell debris.

The protein was then purified to homogeneity using a combination of affinity and anion exchange chromatographies: $5 \mathrm{mM}$ imidazole was added to the crude cell extract which was subsequently applied to a column $(1 \times 10 \mathrm{~cm})$ containing $10 \mathrm{~mL}$ of Ni-NTA resin (BioRad), which takes advantage of the affinity of nickel for the 6-histidine tag, equilibrated with $50 \mathrm{mM}$ Tris- $\mathrm{HCl}(\mathrm{pH} 7.8), 0.5 \mathrm{M} \mathrm{NaCl}$ and $5 \mathrm{mM}$ imidazole. After loading the crude extract, the column was washed with $50 \mathrm{mM}$ Tris- $\mathrm{HCl}(\mathrm{pH} 7.8)$ and $0.5 \mathrm{M} \mathrm{NaCl}$ containing $10 \mathrm{mM}$ imidazole, and the protein was eluted using $50 \mathrm{mM}$ Tris- $\mathrm{HCl}(\mathrm{pH} 7.8)$ and $0.5 \mathrm{M} \mathrm{NaCl}$ containing $1 \mathrm{M}$ imidazole. At this point the presence of the recombinant protein became evident with the appearance of the red color of ferric rubredoxin at the top of the resin. Fractions were analyzed by Tris-glycine buffered $15 \%$ SDS-PAGE and the best fractions in term of purity were pooled and concentrated using an Amicon unit cell, equipped with a YM3 membrane, in view of further purification. The colorless fractions from Ni-NTA column, containing ferrous or zinc rubredoxin, as analyzed by SDS-PAGE, were reconstituted readily with iron. Protein was precipitated by addition of $10 \%$ trichloroacetic acid (TCA) in elution buffer, in presence of $0.5 \mathrm{M} \beta$-mercaptoethanol. After centrifugation, the precipitate was redissolved in $0.5 \mathrm{M}$ Tris base $(\mathrm{pH} 8.0)$ containing $50 \mathrm{mM} \beta$-mercaptoethanol. $\mathrm{FeSO}_{4}$ in slight excess (1.1 equiv) was then added to the protein under anaerobic conditions and let to reoxidize by exposure to air, after what the red protein sample was desalted by passage through a gel filtration NAP-25 (G25) column (Amersham Pharmacia) equilibrated with $25 \mathrm{mM}$ Tris- $\mathrm{HCl}(\mathrm{pH} 8.0)$.

Further purification was performed using a MonoQHR5/5 anion exchange resin, equilibrated with $20 \mathrm{mM}$ Tris- $\mathrm{HCl}(\mathrm{pH} 7.8)$, in order to separate the red ferric iron rubredoxin from residual zinc form, apoprotein and various impurities. After washing with the same buffer, the red protein fractions were eluted from this column using $0.15 \mathrm{M} \mathrm{NaCl}$ in $20 \mathrm{mM}$ Tris- $\mathrm{HCl}(\mathrm{pH} \mathrm{7.8)}$ and appeared homogenously pure judged by Tricine-SDSPAGE [36].

Overexpression and purification of recombinant Dv rubredoxin

Dv rubredoxin was overexpressed and purified to homogeneity following a protocol similar to the one published for the purification of $\mathrm{Dg}$ desulforedoxin [37]. After overexpression of the gene in $E$. coli cells, a typical purification process involved a combination of anion exchange and gel filtration chromatography. Cultures of BL21 (DE3) cells (Novagen, Madison, Wis., USA) containing the rubredoxin gene, previously cloned in our laboratory, were grown at $37^{\circ} \mathrm{C}$ with shaking in LB medium containing ampicillin $(0.1 \mathrm{mg} /$ $\mathrm{mL}$ ), until the absorbance at $595 \mathrm{~nm}$ reached 0.7 , at which point IPTG was added to a final concentration of $1 \mathrm{mM}$. The cells cultures were grown for an additional $6 \mathrm{~h}$ and harvested by centrifugation at $3400 \times g$ for $15 \mathrm{~min}$. The cells were washed and suspended in

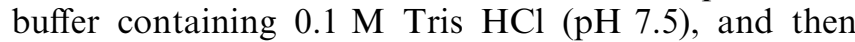
lysed by three passages through a French pressure cell operating at 15,000 p.s.i. at the orifice; the resulting solution was centrifuged at $5000 \times g$ for $15 \mathrm{~min}$. The crude extract was then loaded onto a column $(2.6 \times 35 \mathrm{~cm})$ containing a DEAE-sepharose-CL6B anion exchange resin (Amersham Biosciences), equilibrated with $25 \mathrm{mM}$ Tris- $\mathrm{HCl}(\mathrm{pH}$ 7.5). After washing with the same buffer, the protein was eluted from the column with $25 \mathrm{mM}$ Tris- $\mathrm{HCl}(\mathrm{pH}$ 7.5) containing $0.2 \mathrm{M} \mathrm{NaCl}$. Fractions were collected and assayed for the presence of rubredoxin by measuring the 
absorbance at $490 \mathrm{~nm}$. Red fractions were combined and concentrated and the protein was then loaded onto a column $(2.6 \times 100 \mathrm{~cm})$ containing a Sephadex G75 gel filtration resin (Amersham Biosciences) equilibrated with $25 \mathrm{mM}$ Tris- $\mathrm{HCl}(\mathrm{pH} 7.5)$ containing $0.15 \mathrm{M}$ $\mathrm{NaCl}$, and eluted with the same buffer. Fractions were judged pure as analyzed by Tricine-SDS-PAGE.

Overexpression and purification of recombinant $\mathrm{Tp}$ neelaredoxin

Tp neelaredoxin was cloned, overexpressed and purified to homogeneity using a combination of anion exchange and gel filtration chromatography, as previously described [4].

\section{Oxidation of Tp neelaredoxin}

A sample of oxidized neelaredoxin was obtained by treating a sample of the purified protein with a slight excess of $15 \mathrm{mM} \quad \mathrm{Na}_{2} \mathrm{IrCl}_{6}$ in $50 \mathrm{mM}$ Tris $\mathrm{HCl}$ $(\mathrm{pH} 7.8)$, followed by the removal of the excess of oxidant by passage of the sample over a NAP-25 column (Amersham Biosciences) equilibrated in $50 \mathrm{mM}$ Tris-HCl (pH 7.8). Addition of $\mathrm{Na}_{2} \mathrm{IrCl}_{6}$ resulted in an increase of the absorbance at $656 \mathrm{~nm}$, characteristic of the $\mathrm{Fe}^{3+}$ form of the protein. A slight excess of $\mathrm{Na}_{2} \mathrm{IrCl}_{6}$ was defined as the amount that no longer produced further increase in the absorbance at $656 \mathrm{~nm}$.

\section{Reduction of $\mathrm{Tp}$ rubredoxin}

Reduction of recombinant Tp rubredoxin was accomplished by careful spectrophotometric titration with freshly prepared anaerobic solution of sodium dithionite $\left(E_{\text {midpoint }}=-420 \mathrm{mV}\right)$. A $100 \mathrm{mM}$ sodium dithionite stock solution was first prepared in Tris- $\mathrm{HCl}(\mathrm{pH} 9.0)$ under argon, and then diluted solutions were made and used within a few hours. All the dithionite solutions concentrations were standardized at $420 \mathrm{~nm}$ $\left(\varepsilon=1.02 \mathrm{mM}^{-1} \mathrm{~cm}^{-1}\right)$ [38]. Addition of sodium dithionite resulted in a decrease of the $490-\mathrm{nm}$ feature of the spectrum, characteristic of the $\mathrm{Fe}^{3+}$ form of rubredoxin. The titrations were conducted until the spectrum of fully reduced rubredoxin was obtained, i.e. until disappearance of the $490 \mathrm{~nm}$ absorbance, but before the absorption of excess dithionite was observed.

\section{Iron determination of recombinant $\mathrm{Tp}$ rubredoxin}

Iron determination of purified rubredoxin was determined in parallel using inductively coupled plasma spectrometry (ICP) and 2,4,6-tripyridyl-5-triazine (TPTZ) titration [39], based on the extraction of the protein iron using $\mathrm{HCl}$, following protein precipitation using TCA. Ascorbic acid $10 \%$ was first added to a protein sample, in parallel with iron curve, in addition of $8 \mathrm{M} \mathrm{HCl}$. After vortexing and 10-min incubation, the protein was precipitated using TCA. After centrifugation for $5 \mathrm{~min}$ at $14,000 \times \mathrm{g}$, the supernatant was added to ammonium acetate $(75 \%)$ and hydroxylamine $(10 \%)$. After vortexing, $4 \mathrm{mM}$ TPTZ was added and, after 10 min incubation, the iron molecules complexed to TPTZ to form a blue complex with a maximum of absorbance at $593 \mathrm{~nm}$. For all samples, total protein was assayed using the Bradford method [40].

\section{Direct electron transfer experiments}

Before all kinetic experiments, samples of as-purified rubredoxin were desalted by passage onto a NAP-25 gel filtration column (Amersham Biosciences), and the red fractions containing ferric rubredoxin were saved. Concentration of rubredoxin was deduced from the absorbance of $\mathrm{Fe}^{3+}$ iron at $490 \mathrm{~nm}$, using the calculated molar absorption coefficient $\varepsilon_{490 \mathrm{~nm}}=6.9 \pm 0.4 \mathrm{mM}^{-1} \mathrm{~cm}^{-1}$. The assay was performed aerobically at $20^{\circ} \mathrm{C}$ in a $1-\mathrm{mL}$ quartz cuvette containing approximately $20 \mu \mathrm{M} \mathrm{Fe}{ }^{3+}$ recombinant $\mathrm{Tp}$ rubredoxin (OD $490 \mathrm{~nm} \approx 0.1$ ) in $50 \mathrm{mM}$ phosphate buffer ( $\mathrm{pH}$ 7.8). Reduction of rubredoxin was accomplished by careful spectrophotometric titration with freshly prepared anaerobic solution of sodium dithionite, as described above, leading to the disappearance of the characteristic absorbance of ferric rubredoxin at $490 \mathrm{~nm}$. After 2-3 min in the presence of oxygen, various amounts of $\mathrm{Na}_{2} \mathrm{IrCl}_{6}$-oxidized neelaredoxin were added, resulting in an instantaneous reoxidation of rubredoxin.

\section{Superoxide-mediated electron transfer experiments}

The assays were performed aerobically at $20^{\circ} \mathrm{C}$ in a $1-\mathrm{mL}$ quartz cuvette containing approximately $20 \mu \mathrm{M}$ rubredoxin in $50 \mathrm{mM}$ phosphate buffer ( $\mathrm{pH}$ 7.8). After addition of sodium dithionite as described above, reduction of rubredoxin was reflected by a decrease in the absorbance at $490 \mathrm{~nm}$. After approximately $1 \mathrm{~min}$, xanthine $(0.4 \mathrm{mM})$ and then xanthine oxidase $(0.051 \mathrm{U} /$ $\mathrm{mL}$ ) were added to the cuvette, in order to generate a continuous flux of superoxide of $7 \mu \mathrm{M} / \mathrm{min}$. The amount of superoxide produced was calibrated for every experiment by measuring the rate of reduction of $10 \mu \mathrm{M}$ cytochrome $c$ at $550 \mathrm{~nm}\left(\varepsilon=21 \mathrm{mM}^{-1} \mathrm{~cm}^{-1}\right)$, in the presence of the xanthine/xanthine oxidase system [41]. After addition of xanthine/xanthine oxidase, a slow reoxidation of rubredoxin was observed, but was greatly accelerated by the addition of a catalytic amount of $\mathrm{Na}_{2} \mathrm{IrCl}_{6}$-oxidized neelaredoxin. The specific rubredoxin oxidation rate was derived by comparing the rate of rubredoxin oxidation before and upon addition of neelaredoxin. 


\section{Results}

Cloning, overexpression and purification of recombinant $\mathrm{Tp}$ rubredoxin

The rubredoxin gene was cloned thanks to a construct, labeled pQE30T-Ce5073(1-120), and which simply includes a polyhistidine tag (6-His tag) fused to the Nterminal end of the rubredoxin gene. This plasmid was subsequently used for protein overexpression in $E$. coli and the recombinant rubredoxin was then purified to homogeneity using a combination of affinity and anion exchange chromatography. The presence of $\mathrm{Fe}^{3+} \mathrm{ru}-$ bredoxin was evident as a red-colored band appeared on the top of the first Ni-NTA affinity column, which takes advantage of the affinity of nickel for the histidine tag. However, it has been well described that overexpression of rubredoxin in $E$. coli, which contains no native rubredoxin, results in the production of both iron- and zinc-bound forms [25, 42, 43, 44, 45]. Indeed, the presence of rubredoxin in some of the colorless fractions was confirmed by SDS-PAGE. After iron reconstitution of these colorless fractions, red $\mathrm{Fe}^{3+}$ rubredoxin was separated from remaining zinc protein, apoprotein and last impurities by using anion exchange chromatography. After purification, recombinant rubredoxin presented a single band at around $6 \mathrm{kDa}$ by Tricine-SDS-PAGE, in agreement with the $5568 \mathrm{kDa}$ value calculated from the amino acid sequence.

Spectroscopic characterization of recombinant Tp rubredoxin

As-purified Tp rubredoxin exhibited a red color resulting from the oxidized $\mathrm{Fe}^{3+}$ form of the protein, characterized by a broad peak in the visible region of the optical spectrum with $\lambda_{\max }=490 \mathrm{~nm}$, which has been attributed to a sulfur-to-iron charge transfer transition (Fig. 1, dashed line). The spectrum also exhibits a characteristic shoulder around $350 \mathrm{~nm}$, and bands at 380,570 and $750 \mathrm{~nm}$, also resulting from cysteinyl-toiron charge transfer transitions. These UV-visible features are similar to the ones of rubredoxins from other organisms, such as rubredoxin from Dv, as shown in Fig. 1 (solid line) $[20,22,35,46,47,48]$. Samples of recombinant rubredoxin were analyzed for iron using ICP and parallel iron titration using the TPTZ assay, as described in Material and methods [39]. The two methods gave similar results and allowed us to calculate the molar absorption coefficient of the $490 \mathrm{~nm}$ feature of the spectrum, specific for the $\mathrm{Fe}^{3+}$ form of the enzyme, of $\varepsilon=6.9 \pm 0.4 \mathrm{mM}^{-1} \mathrm{~cm}^{-1}$. This value is also in good agreement with previous published values for rubredoxins from Clostridium pasteurianum $(\varepsilon=$ $\left.8.85 \mathrm{mM}^{-1} \mathrm{~cm}^{-1}\right)[22,23], \mathrm{Dv}\left(\varepsilon=6.9 \mathrm{mM}^{-1} \mathrm{~cm}^{-1}\right)$ [20, 35], Desulfovibrio desulfuricans $\left(\varepsilon=6.9 \mathrm{mM}^{-1} \mathrm{~cm}^{-1}\right)$ [46] or $\operatorname{Dg}\left(\varepsilon=6.6 \mathrm{mM}^{-1} \mathrm{~cm}^{-1}\right)$ [48]. Interestingly, the ratio

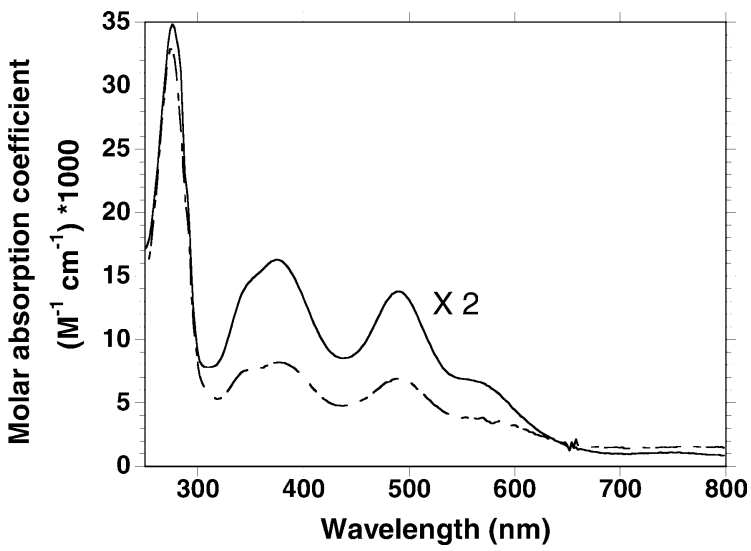

Fig. 1 UV-visible spectra of Tp and Dv recombinant rubredoxins. Dashed line: optical spectrum of a $7.5 \mu \mathrm{M}$ solution of $\mathrm{Tp}$ rubredoxin in $50 \mathrm{mM}$ phosphate buffer $(\mathrm{pH} \mathrm{7.8)}$ after iron reconstitution, as described in Material and methods. The $A_{280} /$ $A_{490}$ ratio is 4.4. Full line: optical spectrum $(\times 2)$ of a $30 \mu \mathrm{M}$ solution of Dv rubredoxin in $50 \mathrm{mM}$ phosphate buffer ( $\mathrm{pH} 7.8)$. The $A_{280} /$ $A_{490}$ ratio is 2.4

of the absorbances at $490 \mathrm{~nm}$ and $280 \mathrm{~nm}$, which reflects the relative amounts of ferric protein and apoprotein (or zinc protein) still present in the mixture after iron reconstitution, happened to be different in the case of $\mathrm{Tp}$ and Dv rubredoxins, respectively of 4.4 and 2.4 (Fig. 1). In addition, parallel iron and protein measurements showed respective iron/protein ratios of $48 \%$ for $\mathrm{Tp}$ and $63 \%$ for Dv. Calculation of the molar absorption coefficient of the two proteins at $280 \mathrm{~nm}$, using the method of Edelhoch, based on the amino acid sequence, gave the values of $\varepsilon=14.8 \mathrm{mM}^{-1} \mathrm{~cm}^{-1}$ for Tp rubredoxin and $\varepsilon=10.6 \mathrm{mM}^{-1} \mathrm{~cm}^{-1}$ for $\mathrm{Dv}$ rubredoxin, a difference mainly due to the presence of an additional tryptophan in the Tp rubredoxin sequence $[49,50,51]$.

The low-temperature EPR spectrum of recombinant Tp rubredoxin was also recorded (data not shown). The spectrum is essentially rhombic, with a pronounced feature at $g=4.3$, and a shoulder at $g=9.4(E / D=0.28)$, characteristic of a high-spin iron $S=5 / 2$, and very similar to previously published EPR spectra of rubredoxin $[13,24,26,48,52,53]$.

\section{Electrochemical measurements}

The electrochemical response of $\mathrm{Tp}$ rubredoxin on the GC electrode is shown in Fig. 2. The cyclic voltammogram presents the current peak due to the redox process $\left[\mathrm{Fe}(\mathrm{S}-\mathrm{Cys})_{4}{ }^{3+}\right] /\left[\mathrm{Fe}(\mathrm{S}-\mathrm{Cys})_{4}{ }^{2+}\right]$ that occurs at the metallic center of the protein. The results point to a heterogeneous rate constant, $k_{\mathrm{s}, \mathrm{h}}=3 \times 10^{-5} \mathrm{~cm}^{-1} \mathrm{~s}^{-1}$, calculated using the method of Laviron, in agreement with electrochemical quasi-reversible behavior [54]. The mean value of the oxidation and the reduction peak current potentials, $\left(E_{\mathrm{pa}}+E_{\mathrm{pc}}\right) / 2$, remains constant within the imposed conditions. The formal reduction potential, $E^{\mathrm{o} \prime}$, was estimated by the $\left(E_{\mathrm{pa}}+E_{\mathrm{pc}}\right) / 2$ values, 


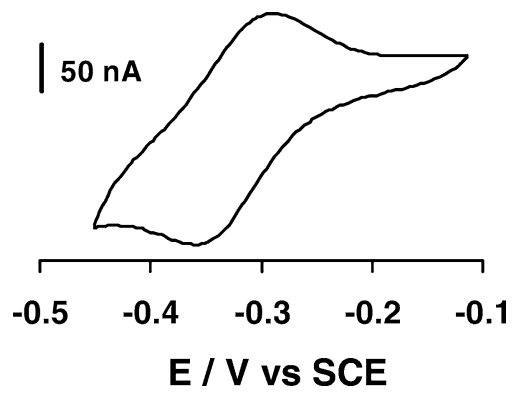

Fig. 2 Cyclic voltammogram of $\mathrm{Tp}$ rubredoxin on the GC electrode $(v=1 \mathrm{mV} / \mathrm{s})$

and the $E^{\mathrm{O}}$ found for the $\mathrm{Rd}$ redox process was $-76 \pm 5 \mathrm{mV}$. This value was found to be slightly more negative than the ones already published for rubredoxins from different organisms, suggesting that $\mathrm{Tp}$ rubredoxin presents a more reducing behavior [55, 56, 57, 58].

Evidence for direct electron transfer between recombinant $\mathrm{Tp}$ rubredoxin and neelaredoxin

In order to validate the role of rubredoxin as an electron donor for neelaredoxin, reduction of Tp rubredoxin was accomplished by addition of a slight excess of a freshly prepared anaerobic solution of sodium dithionite, which resulted in a loss of the $490 \mathrm{~nm}$ absorbance of ferric rubredoxin (Fig. 3). The amount of sodium dithionite added was carefully controlled to perform a full reduction of rubredoxin but to avoid a possible uncontrolled

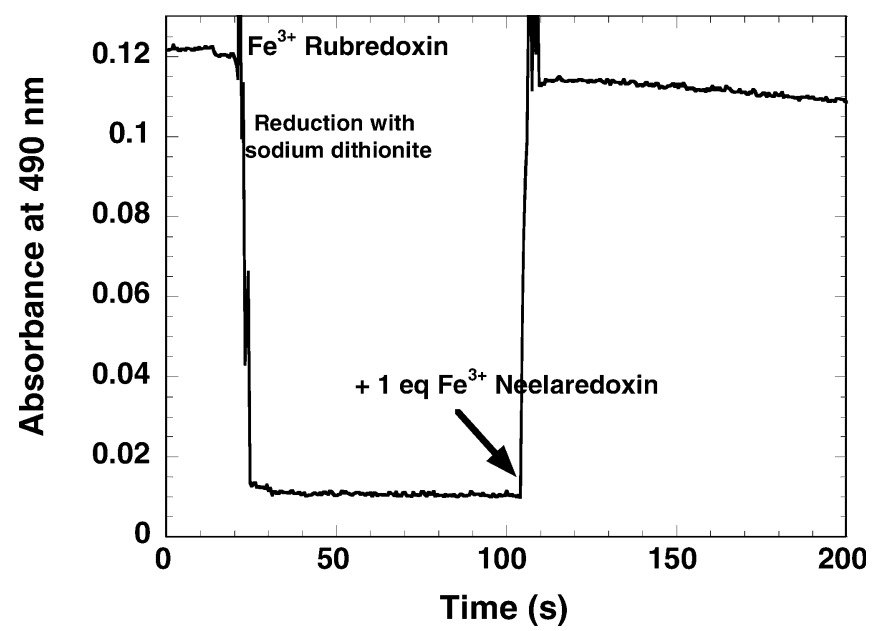

Fig. 3 Evidence for a direct electron transfer between Tp rubredoxin and $\mathrm{Tp}$ neelaredoxin. The experiment was performed aerobically at $20^{\circ} \mathrm{C}$ in a $1-\mathrm{mL}$ quartz cuvette containing $17.5 \mu \mathrm{M}$ $\mathrm{Fe}^{3+}$ recombinant $\mathrm{Tp}$ rubredoxin in $50 \mathrm{mM}$ phosphate buffer $(\mathrm{pH}$ 7.8). Reduction of rubredoxin was accomplished by careful spectrophotometric titration with a freshly prepared anaerobic solution of sodium dithionite, leading to the disappearance of the characteristic absorbance of ferric rubredoxin at $490 \mathrm{~nm}$. After 3 min, 1 equiv of $\mathrm{Na}_{2} \mathrm{IrCl}_{6}$-oxidized Tp neelaredoxin was added, resulting in a full reoxidation of rubredoxin reduction of neelaredoxin and the presence of dithionite degradation products, which could interfere with the observed reaction. Figure 3 shows that, after around 2 min of oxygen incubation, addition of 1 equiv of $\mathrm{Na}_{2} \mathrm{IrCl}_{6}$-oxidized neelaredoxin (calculated using $\varepsilon_{656}=2.6 \mathrm{mM}^{-1} \mathrm{~cm}^{-1}$ ) resulted in an immediate reoxidation of a $17.5 \mu \mathrm{M}$ solution of Tp rubredoxin (calculated from the absorbance of $\mathrm{Fe}^{3+}$ iron at $490 \mathrm{~nm}$, using the determined molar absorption coefficient $\left.\varepsilon_{490}=6.9 \pm 0.4 \mathrm{mM}^{-1} \mathrm{~cm}^{-1}\right)$. Similar experiments were performed using various concentrations of $\mathrm{Na}_{2} \mathrm{IrCl}_{6^{-}}$ oxidized neelaredoxin, and also resulted in an instantaneous increase of the absorbance at $490 \mathrm{~nm}$, revealing the reoxidation of rubredoxin upon addition of neelaredoxin. Moreover, the extent of rubredoxin reoxidation was directly proportional to the amount of neelaredoxin added, as shown in Fig. 4, demonstrating the existence of a direct electron transfer from reduced $\mathrm{Fe}^{2+}$ rubredoxin to oxidized $\mathrm{Fe}^{3+}$ neelaredoxin. The calculated slope of the linear part of Fig. 4 was 0.95 $\left(r^{2}=0.99\right)$, showing that about one molecule of rubredoxin was oxidized for each molecule of neelaredoxin added. This stoichiometry of 1:1 for the direct electron transfer reaction between reduced rubredoxin and oxidized neelaredoxin is in good agreement with the following equation:

$\mathrm{Rd} \mathrm{Fe}^{2+}+\mathrm{Nlr} \mathrm{Fe}^{3+} \rightarrow \mathrm{Rd} \mathrm{Fe}^{3+}+\mathrm{Nlr} \mathrm{Fe}^{2+}$

Similarly, when following the reaction at $656 \mathrm{~nm}$, addition of $\mathrm{Fe}^{2+}$ rubredoxin to $\mathrm{Fe}^{3+}$ neelaredoxin resulted in an instantaneous decrease of the $656 \mathrm{~nm}$ feature of $\mathrm{Fe}^{3+}$ neelaredoxin (data not shown). After full reoxidation of rubredoxin, only a slight reduction of rubredoxin was observed at $490 \mathrm{~nm}$, as shown at the end

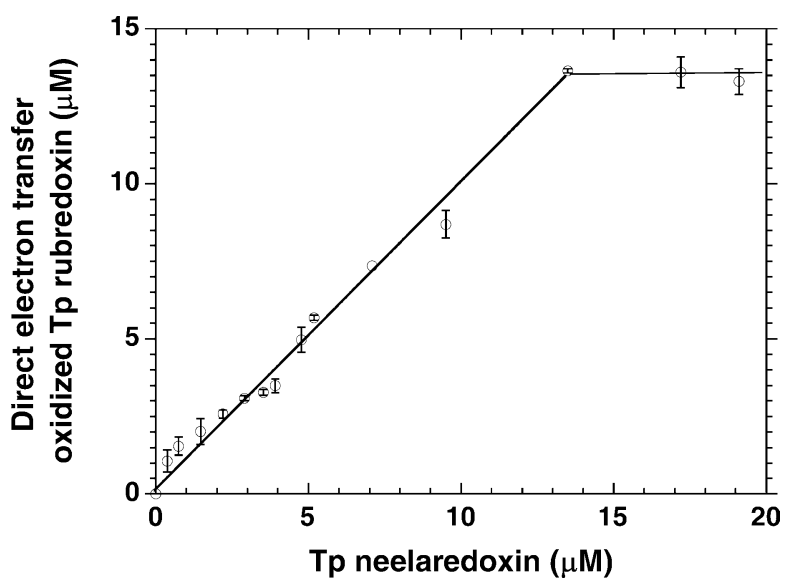

Fig. 4 Direct electron transfer oxidized Tp rubredoxin $(\mu \mathrm{M})$ in the presence of different concentrations of $\mathrm{Na}_{2} \mathrm{IrCl}_{6}$-oxidized $\mathrm{Tp}$ neelaredoxin. The experiment was performed as described in the legend of Fig. 3, with an initial rubredoxin concentration of $13.5 \mu \mathrm{M}$. The amount of oxidized rubredoxin was then calculated from the difference of absorbance at $490 \mathrm{~nm}$ observed before and immediately upon addition of various concentrations of $\mathrm{Na}_{2} \mathrm{IrCl}_{6^{-}}$ oxidized neelaredoxin, using the calculated molar absorption coefficient of $\epsilon=6.9 \mathrm{mM}^{-1} \mathrm{~cm}^{-1}$ at $490 \mathrm{~nm}$ 
of the Fig. 3 kinetics, in agreement with a displacement of the equilibrium of Eq. 2 toward the acceptance of an electron from rubredoxin. This is in agreement with the difference of the midpoint potential values of the two species, $E_{\text {midpoint }}\left(\mathrm{Nlr} \mathrm{Fe}^{3+} / \mathrm{Nlr} \mathrm{Fe}^{2+}\right)=+220 \mathrm{mV}$ for neelaredoxin [4] and our calculated $E_{\text {midpoint }}\left(\mathrm{Rd} \mathrm{Fe}^{3+} /\right.$ $\mathrm{Rd} \mathrm{Fe}^{2+}=-76 \pm 5 \mathrm{mV}$ ) for rubredoxin, which tends to favor the donation of electrons from rubredoxin to neelaredoxin. The slight reduction observed at the end of the kinetics of Fig. 3 could be explained by the continuous natural rearrangement of the equilibrium between the ferrous and ferric forms of rubredoxin.

Figure 5 presents kinetics of the electron transfer reaction between reduced rubredoxin and different concentrations of $\mathrm{Na}_{2} \mathrm{IrCl}_{6}$-oxidized neelaredoxin, varying from 0.22 to 1 equiv. Interestingly, despite the stoichiometry of $1: 1$ for the direct electron transfer reaction calculated from Fig. 4, biphasic kinetics was always observed for less than 1 equiv of neelaredoxin added (Fig. 5a-c). In the first phase, the direct electron transfer between the two proteins resulted in an instantaneous reoxidation of rubredoxin, characterized by a jump in absorbance at $490 \mathrm{~nm}$, and the difference of absorbance corresponded to the amount of rubredoxin oxidized via direct electron transfer (Fig. 5). The extent of this instantaneous increase in absorbance was directly proportional to the concentration of neelaredoxin added, in agreement with a direct electron transfer reaction and the data of Fig. 4. However, in a second phase, as shown in the kinetics of Fig. 5a-c, a slow reoxidation was observed, with an average rate of $3.5 \mu \mathrm{M} / \mathrm{min}$, which was not dependent of the concentration of neelaredoxin, and leading to a full reoxidation of rubre-

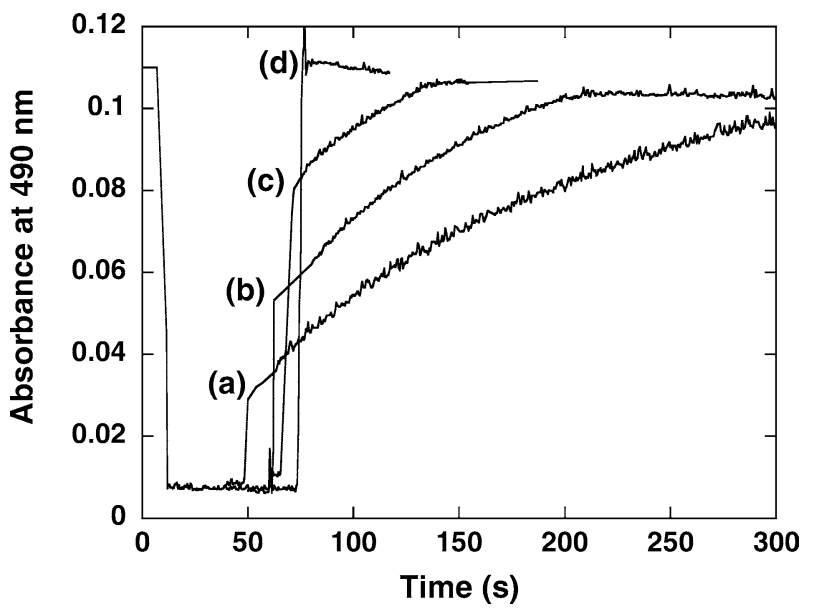

Fig. 5 Kinetics of direct electron transfer between Tp rubredoxin and various concentrations of $\mathrm{Na}_{2} \mathrm{IrCl}_{6}$-oxidized $\mathrm{Tp}$ neelaredoxin. The experiment was performed aerobically at $20^{\circ} \mathrm{C}$ in a $1-\mathrm{mL}$ quartz cuvette containing $16 \mu \mathrm{M} \mathrm{Fe}^{3+}$ recombinant Tp rubredoxin in $50 \mathrm{mM}$ phosphate buffer $(\mathrm{pH} 7.8)$. After reduction of rubredoxin using a freshly prepared anaerobic solution of sodium dithionite, various equivalents of $\mathrm{Na}_{2} \mathrm{IrCl}_{6}$-oxidized $\mathrm{Tp}$ neelaredoxin (Tp Nlr) were added: (a) 0.22 equiv $(3.6 \mu \mathrm{M}) ;(b) 0.45$ equiv $(7.2 \mu \mathrm{M}) ;(c) 0.7$ equiv $(11 \mu \mathrm{M}) ;(d) 1$ equiv $(16 \mu \mathrm{M})$ doxin. Interestingly, similar spontaneous rubredoxin reoxidation was observed, with a similar rate, in the case of only a partial reduction of rubredoxin using sodium dithionite (data not shown). Moreover, addition of oxidized $\mathrm{Fe}^{3+}$ rubredoxin to reduced $\mathrm{Fe}^{2+}$ rubredoxin also resulted in a reoxidation of rubredoxin with a rate identical to the one observed in the second phase of our electron transfer experiments of $3.5 \mu \mathrm{M} / \mathrm{min}$. However, no oxygen-mediated rubredoxin oxidation was ever observed (Fig. 3). We postulate here that the slight excess of dithionite used to reduce rubredoxin protects the protein from an uncontrolled aerobic reoxidation.

Altogether, these results reveal the existence of direct electron transfer between the two proteins, but the rate of exchange was too fast to be accurately measured. Moreover, no reoxidation could be observed below 0.1 equiv neelaredoxin, partly due to the limit of detection of the spectrophotometer.

Evidence for a superoxide-mediated electron transfer from Dv and Tp rubredoxins to Tp neelaredoxin

To evaluate the role of rubredoxin as an individual electron donor for neelaredoxin in physiological conditions, reoxidation of dithionite-reduced rubredoxin was measured in the presence of a catalytic amount of superoxide reductase, and of a steady-state concentration of superoxide anion, the physiological substrate of the enzyme. Reduced rubredoxin was first produced by adding freshly anaerobically prepared sodium dithionite, as previously described. No spontaneous reoxidation of rubredoxin was observed in the presence of oxygen and, after $1 \mathrm{~min}$, xanthine $(0.15 \mathrm{mM})$ and xanthine oxidase $(0.051 \mathrm{U} / \mathrm{mL})$ were added to the reaction mixture, in order to produce a continuous flux of $\sim 7 \mu \mathrm{M} / \mathrm{min}$ superoxide (Fig. 6) [41]. Addition of xanthine/xanthine oxidase resulted in a slow reoxidation of rubredoxin, as shown in Fig. 6, with an average rate of $1.5 \mu \mathrm{M} / \mathrm{min}$. After 1-2 min of further incubation, addition of a catalytic amount of neelaredoxin (rubredoxin/neelaredoxin $=80-5000)$ to the system resulted in an acceleration of the rate of reoxidation of rubredoxin (Fig. 6). These results show that, in presence of a catalytic amount of neelaredoxin, superoxide acts as a trigger for the reoxidation of rubredoxin, in agreement with the following equation:

$2 \mathrm{H}^{+}+\mathrm{Rd} \mathrm{Fe}^{2+}+\mathrm{O}_{2}^{-} \stackrel{\text { neelaredoxin }}{\longrightarrow} \mathrm{Rd} \mathrm{Fe}^{3+}+\mathrm{H}_{2} \mathrm{O}_{2}$

Moreover, addition of bovine SOD in this experiment did not result in a reoxidation of rubredoxin, in agreement with the specificity of electron donation from rubredoxin to superoxide reductase (data not shown). Indeed, $\mathrm{Cu}-\mathrm{Zn}$ SOD, with a $E_{\text {midpoint }}\left(\mathrm{Cu}^{2+}\right.$; $\left.\mathrm{Cu}^{+}\right)=+47 \pm 5 \mathrm{mV}$ [59], is less able than SOR [ $E_{\text {midpoint }}$ $\left.\left(\mathrm{Nlr} \mathrm{Fe}^{3+} / \mathrm{Nlr} \mathrm{Fe}^{2+}\right)=+220 \mathrm{mV}\right]$ to accept electrons from rubredoxin $\left[E_{\text {midpoint }}\left(\mathrm{Rd} \quad \mathrm{Fe}^{3+} / \mathrm{Rd} \quad \mathrm{Fe}^{2+}\right)=\right.$ $-76 \mathrm{mV}$ ] at a rate sufficient to outcompete the catalytic 


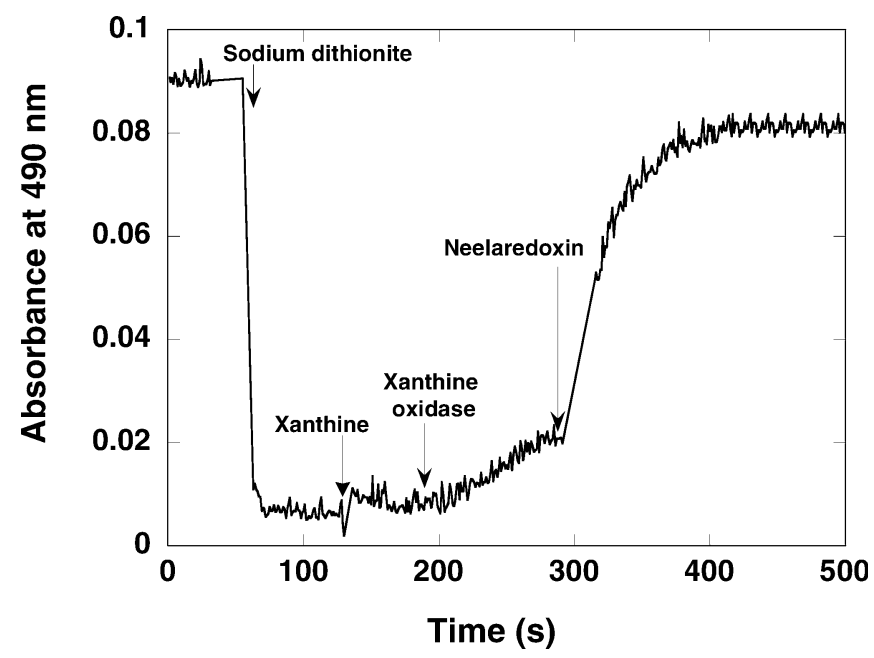

Fig. 6 Kinetics of superoxide-mediated electron transfer between $\mathrm{Tp}$ rubredoxin and $\mathrm{Tp}$ neelaredoxin, at $490 \mathrm{~nm}$. The assay was performed aerobically at $20^{\circ} \mathrm{C}$ in a $1-\mathrm{mL}$ quartz cuvette containing $13 \mu \mathrm{M}$ rubredoxin in $50 \mathrm{mM}$ phosphate buffer $(\mathrm{pH} 7.8)$. After addition of sodium dithionite, reduction of rubredoxin was reflected by a decrease in the absorbance at $490 \mathrm{~nm}$. After approximately $1 \mathrm{~min}$, xanthine $(0.4 \mathrm{mM})$ and then xanthine oxidase $(0.051 \mathrm{U} / \mathrm{mL})$ were added to the cuvette, resulting in a slow reoxidation of rubredoxin, which was greatly accelerated by the addition of $0.15 \mu \mathrm{M}$ of $\mathrm{Na}_{2} \mathrm{IrCl}_{6}$-oxidized $\mathrm{Tp}$ neelaredoxin $($ ratio rubredoxin $/$ neelaredoxin $=87$ )

disproportionation of $\mathrm{O}_{2}^{-}$by $\mathrm{SOD}$, of $2.5 \times 10^{9} \mathrm{M}^{-1} \mathrm{~s}^{-1}$ at pH $7.8[60,61,62]$. However, SOD was able to compete with SOR in this assay and inhibited the reoxidation of rubredoxin, being then in competition with SOR toward the superoxide anion (data not shown).

The rate of rubredoxin reoxidation was then calculated from differences between the rates of rubredoxin oxidation before and upon addition of various amounts of neelaredoxin. This rate of $\mathrm{Tp}$ rubredoxin reoxidation, presented in Fig. 7 (open circles), was found to be directly proportional to the concentration of $\mathrm{Tp}$ neelaredoxin added to the reaction mixture, as expected for a bimolecular enzymatic reaction, and confirmed a direct electron transfer between the two proteins. The linear regression of the curve of Fig. 7 (open circles) gave a specific activity of $181 \mathrm{~min}^{-1}$ for the electron transfer reaction between $\mathrm{Tp}$ rubredoxin and neelaredoxin. For concentrations of neelaredoxin superior to $0.01 \mu \mathrm{M}$ (ratio $\mathrm{Rd} / \mathrm{Nlr} \approx 1500$ ), the rate of rubredoxin reoxidation rate reached a plateau (data not shown), due to the gradual exhaustion of superoxide produced by the xanthine/xanthine oxidase system, which is the limiting step of the system. However, under our experimental conditions, we can consider the concentration of superoxide as a steady state in the linear part of the plot, and propose that the slope of Fig. 7 is reflecting a $k$ apparent $\left(k_{\text {app }}\right)$ of the electron transfer reaction, in agreement with the following equation:

$v=k\left[\mathrm{O}_{2}^{-}\right][\mathrm{Rd}][\mathrm{Nlr}]=k_{\text {app }}[\mathrm{Nlr}]$

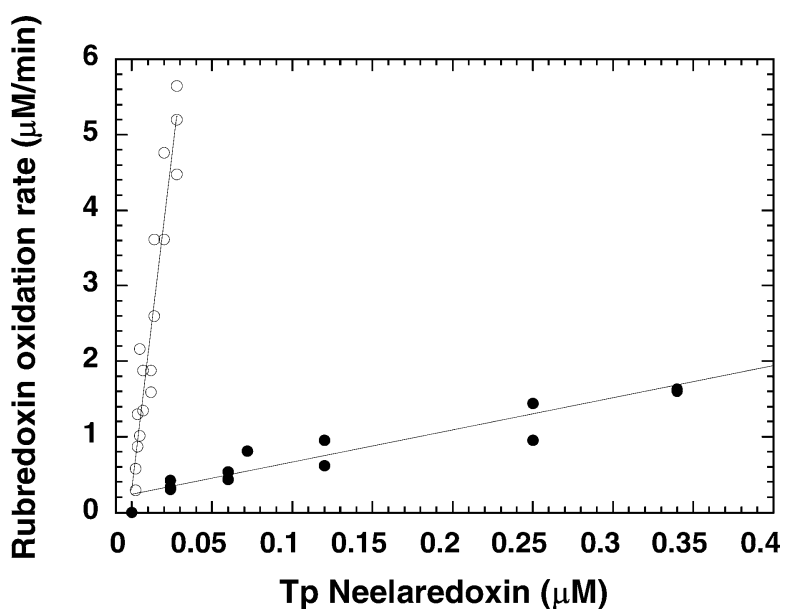

Fig. 7 Superoxide-mediated electron transfer from Tp rubredoxin (open circles) and Dv rubredoxin (solid circles) to Tp neelaredoxin. Experiments were performed as described in the legend of Fig. 6, in presence of various concentrations of $\mathrm{Na}_{2} \mathrm{IrCl}_{6}$-oxidized $\mathrm{Tp}$ neelaredoxin. The specific rubredoxin oxidation rates were derived by comparing the rate of rubredoxin oxidation before and upon addition of neelaredoxin

For comparison, similar experiments were performed using the Dv rubredoxin, which, interestingly, was also able to transfer electrons to $\mathrm{Tp}$ neelaredoxin, with a much lower specific activity of $4.5 \mathrm{~min}^{-1}$, as shown in Fig. 7 (solid circles). Comparison of the two plots of Fig. 7 revealed an acceleration by a factor 40 when rubredoxin and neelaredoxin were both purified from $\mathrm{Tp}$, despite a 57\% sequence homology between $\mathrm{Tp}$ and Dv rubredoxins. These results show unequivocally that, in presence of catalytic amounts of neelaredoxin, reoxidation of rubredoxin can only occur in presence of the physiological substrate of the enzyme, the superoxide anion, which confirms the role of rubredoxin as the physiological electron donor for Tp superoxide reductase.

\section{Discussion}

We report here the first cloning, overexpression in $E$. coli and purification of a recombinant rubredoxin from Tp. Interestingly, even though the purification of Dv rubredoxin, which presents $57 \%$ sequence homology with the one from $\mathrm{Tp}$ and the same acidic isoelectric point around 3.9 [20,63], was routinely performed in our laboratory, we had to elaborate a new strategy to obtain good expression levels of Tp rubredoxin, mainly because the gene appeared to be toxic to the cells. Moreover, iron reconstitution was always necessary during the purification of $\mathrm{Tp}$ rubredoxin, after the NiNTA first chromatography, in order to obtain a protein preparation homogeneous in iron. Nevertheless, the different spectroscopic properties of as-purified $\mathrm{Tp}$ rubredoxin, such as UV-visible and low-temperature EPR spectra, were in good agreement with previously 
published data $[20,22,35,46,47,48]$, as well as the calculated molar absorption coefficient of the $\mathrm{Fe}^{3+}$ feature at $490 \mathrm{~nm}, \varepsilon=6.9 \pm 0.4 \mathrm{mM}^{-1} \mathrm{~cm}^{-1}$. Moreover, we determined the midpoint potential of the protein, of $-76 \pm 5 \mathrm{mV}$, which was also in agreement with midpoint potentials of rubredoxins from other organisms $[55,56,57,58]$. Since it is not technically feasible to isolate rubredoxin directly from $\mathrm{Tp}$, in amounts necessary for detailed mechanistic and spectroscopic studies, overexpressing the recombinant forms of rubredoxin in the heterologous host E. coli is an important step for future studies of the full metabolic pathway of the syphilis spirochete.

Mixing of $\mathrm{Fe}^{2+}$ rubredoxin and $\mathrm{Fe}^{3+}$ neelaredoxin in proportions varying from 0.1 to 1 equivalent revealed the existence of a direct instantaneous electron transfer between the two proteins, with a stoichiometry of one molecule of reoxidized rubredoxin per molecule of neelaredoxin added to the medium (Figs. 3 and 4). Moreover, this electron transfer reaction was practically irreversible, in agreement with the difference of midpoint potentials between the two proteins $\left\{E_{\text {midpoint }}\left(\mathrm{Nlr} \mathrm{Fe}^{3+} /\right.\right.$ Nlr $\left.\mathrm{Fe}^{2+}\right)=+220 \mathrm{mV}$ [4] and $E_{\text {midpoint }}\left(\mathrm{Rd} \mathrm{Fe}^{3+} / \mathrm{Rd}\right.$ $\left.\left.\mathrm{Fe}^{2+}\right)=-76 \pm 5 \mathrm{mV}\right\}$, which favors the donation of electrons from reduced rubredoxin to oxidized neelaredoxin. In this experiment, rubredoxin was artificially reduced by careful titration using sodium dithionite, and no spontaneous reoxidation of dithionite-reduced rubredoxin was ever observed in the presence of oxygen, in opposition to previous work, including one of our publications [7, 20, 64]. However, we postulate that this apparent discrepancy was only due to the slight excess of sodium dithionite used to reduce the protein. Indeed, in case of incomplete reduction of rubredoxin, a spontaneous reoxidation was observed, which could interfere with the electron transfer reaction and the observed kinetics. Inversely, a too large excess of dithionite would result in the reduction of neelaredoxin and the possible production of dithionite degradation products able to react with superoxide and mask the rubredoxin reoxidation [65]. Under our experimental conditions, the presence of a carefully controlled minor excess of sodium dithionite, coupled to the relatively low midpoint potential value of $\mathrm{Tp}$ rubredoxin, prevented the uncontrolled aerobic reoxidation of rubredoxin, and allowed a more accurate determination of the rubredoxin reoxidation rates.

To validate the role of rubredoxin as an electron donor for SOR in catalytic conditions, a similar experiment was performed but in the presence of the xanthine/xanthine oxidase system, classically used to generate a continuous flux of superoxide anion in SOD assays [41], and catalytic amounts of neelaredoxin. Once again, no oxygen-mediated reoxidation of rubredoxin was ever observed, but a slight reoxidation occurred upon addition of xanthine/xanthine oxidase, as shown in Fig. 6, with a rate of $1.5 \mu / \mathrm{min}$. This reoxidation was shown to be SOD dependent and not catalase dependent (data not shown), as already observed
$[7,64]$ in the case of Pyrococcus furiosus and Tp SORs, and was then attributed to a slight reoxidation of rubredoxin by the superoxide anion, in agreement with the midpoint potentials of both species $\left[E_{\text {midpoint }}\right.$ $\left(\mathrm{O}_{2} / \mathrm{O}_{2}^{-}\right)=+890 \mathrm{mV}$ and $E_{\text {midpoint }}\left(\mathrm{Rd} \quad \mathrm{Fe}^{3+} / \mathrm{Rd}\right.$ $\left.\left.\mathrm{Fe}^{2+}\right)=-76 \pm 5 \mathrm{mV}\right]$. In the presence of this superoxide generating system, addition of neelaredoxin in catalytic amounts ( $\mathrm{Rd} / \mathrm{Nlr}$ from 80 to 5000) resulted in an acceleration of the reoxidation rate of rubredoxin. These results show that, in presence of a steady-state concentration of the physiological substrate of SOR, neelaredoxin was able to catalyze the reoxidation of dithionite-reduced rubredoxin, in good agreement with similar experiments performed with $P$. furiosus SOR [7]. When bovine SOD was added to the system, the rate of rubredoxin reoxidation remained unchanged, because SOD is unable to receive electrons from any component of the reaction system at rates able to outcompete with the catalytic reduction of superoxide $\left(10^{9} \mathrm{M}^{-1} \mathrm{~s}^{-1}\right)[6,16,17,18]$. However, when SOD was added in place of SOR, reoxidation of rubredoxin was totally inhibited, which confirmed the superoxidemediated character of the observed electron transfer reaction. Moreover, the calculated rate of rubredoxin reoxidation was directly proportional to the concentration of neelaredoxin added to the reaction mixture, in agreement with a catalytic reaction and a direct electron transfer between the two proteins, and allowed us to estimate the specific activity of electron transfer from $\mathrm{Tp}$ rubredoxin to neelaredoxin, of $181 \mathrm{~min}^{-1}$ (Fig. 7). Under our experimental conditions, we can assume a steady-state concentration of superoxide, and of less than saturating concentrations of SOR, so the rate-limiting step of the process must be the reaction of SOR with superoxide or rubredoxin. To be efficient, rubredoxin must transfer electrons at a rate able to compete with the spontaneous disproportionation of superoxide, of $5 \times 10^{5} \mathrm{M}^{-1} \mathrm{~s}^{-1}$ at $\mathrm{pH} 7.8$. Under these conditions, we postulate that the slope of the plots of Fig. 7 reflect the $k_{\text {app }}$ of the electron transfer reaction between rubredoxin and neelaredoxin, and allow us to estimate the efficiency of the electron transfer. Interestingly, a similar electron transfer reaction was observed between Dv rubredoxin and $\mathrm{Tp}$ neelaredoxin, but with a much lower efficiency, with a calculated $k_{\text {app }}=4.5 \mathrm{~min}^{-1}$. This confirms the specificity of the electron transfer reaction, despite a $57 \%$ sequence homology between the two rubredoxins, and further investigations are currently performed in our laboratory to try to map the surface of the protein-protein interactions.

The lack of a good quantitative assay for superoxide reductases has made research hard since the function of these enzymes has been discovered, because of the difficulties of assaying superoxide and of the myriad of redox reactions that can take place between compounds in the assay. In the beginning, classic superoxide dismutase assays, such as the reduction of cytochrome $c$ by superoxide at $550 \mathrm{~nm}$ [41], were used to assay SORs, 
resulting in discrepancies in the literature $[4,6,7,9,17$, $66,67]$. It is now currently admitted that superoxide reductases present no, or very low, superoxide dismutase activity that could outcompete the spontaneous disproportionation of superoxide, and that a good assay for superoxide reductases should be specific and allow us to clearly differentiate the dismutation reaction from the reduction of superoxide catalyzed by SORs. This is even more important in the case of Tp, where SORs and SODs are present in similar intracellular concentrations, varying from 25 to $100 \mu \mathrm{M}[4,68]$. The first specific activity assay for SORs was proposed by Kurtz and coworkers [20, 21]. In this work, Dv rubredoxin was shown to be able to transfer electrons to Dv SOR, by creating in vitro the following artificial electron transfer chain: $\mathrm{NADPH} /$ flavin ferredoxin spinach NADPH:superoxide oxidoreductase/rubredoxin/SOR, and measuring the consumption of NADPH resulting from the electron transfer reaction. With this method, the activity of superoxide reductase, derived from the NADPH consumption rate, was measured with a detection limit of around $50 \mathrm{nM}$. Interesting results were also obtained by generating superoxide using pulse radiolysis, but this method is very difficult to use as a routine assay in a laboratory [17]. Here we propose that, with the rate of rubredoxin reoxidation being directly related to the concentration of neelaredoxin, our experiment could be used as an alternative more direct assay, at least for Dv and $\mathrm{Tp}$ superoxide reductases, with a detection limit of less than $5 \mathrm{nM}$. We are now extending this work to validate this assay to the measurement of SOR activities in various anaerobic organisms.

This paper presents the first kinetic evidence for an electron transfer chain in vitro involving $\mathrm{Tp}$ rubredoxin and neelaredoxin, and leading to the reduction of superoxide in the syphilis spirochete, in agreement with the scheme of Fig. 8; however, in vivo, the superoxide reduction within the cell depends on the presence of a cellular system able to reduce the rubredoxin-oxidized iron center for a complete catalytic cycle. In P. furiosus, the presence of a three-component electron-transferring

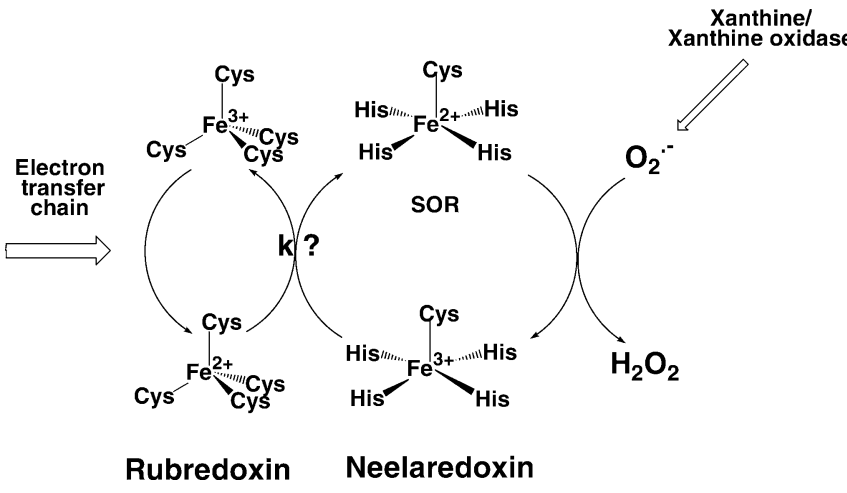

Fig. 8 Part of the electron transfer pathway implicated in the superoxide detoxification of $\mathrm{Tp}$ : scheme of electron transfer between rubredoxin and the superoxide reductase neelaredoxin chain, including $\mathrm{NAD}(\mathrm{P}) \mathrm{H}, \mathrm{NAD}(\mathrm{P}) \mathrm{H}$ oxidoreductase and rubredoxin, was proposed to provide the electrons necessary to achieve the superoxide reduction. The physiologically rate-determining step for superoxide reduction will necessarily be the slowest step in this chain, probably the rate of electron transfer from NADPH to the active site of SOR [7]. To support this hypothesis, an NADPH:rubredoxin oxidoreductase has already been characterized in the case of $P$. furiosus [69]. Moreover, it has been shown that Dv superoxide reductase can be the final electron acceptor of a NADPH/NADPH oxidoreductase/rubredoxin electron transfer chain in vitro $[20,21]$. In Tp, analysis of the full genome shows the presence of homologues for the additional constituents of a primitive SOR-dependent oxygen detoxification pathway, including NADH oxidase, rubredoxin, thioredoxin reductase, thioredoxin, and the $\mathrm{C}$ subunit of an alkyl hydroperoxide reductase [3], then having all the activities required for the complete reduction of superoxide. Testing this scheme of dioxygen detoxification will require a multidisciplinary approach but, ultimately, comparative functional analysis of these pathways in vivo and in vitro may reveal a relationship between $\mathrm{Tp}$ oxidative stress response and syphilis pathogenesis.

Acknowledgements The authors would like to thank Prof. Brian Volkman, from the Medical College of Wisconsin, who generously provided the construct for the Tp rubredoxin. This work is dedicated to the memory of Prof. Frank Rusnak, who tragically passed away on 7 September 2002.

\section{References}

1. Cox D, Riley B, Chang P, Sayahtahery S, Tassell S, Hevelone J (1990) Appl Environ Microbiol 56:3063-3072

2. Cover WH, Norris SJ, Miller JN (1982) Sex Transm Dis 9:1-8

3. Fraser CM, Norris SJ, Weinstock GM, White O, Sutton GG, Dodson R, Gwinn M, Hickey EK, Clayton R, Ketchum KA, Sodergren E, Hardham JM, McLeod MP, Salzberg S, Peterson J, Khalak H, Richardson D, Howell JK, Chidambaram M, Utterback T, McDonald L, Artiach P, Bowman C, Cotton MD, Venter JC, et al. (1998) Science 281:375-388

4. Jovanovic T, Ascenso C, Hazlett KR, Sikkink R, Krebs C, Litwiller R, Benson LM, Moura I, Moura JJ, Radolf JD, Huynh BH, Naylor S, Rusnak F (2000) J Biol Chem 275:28439-28448

5. Lombard M, Touati D, Fontecave M, Niviere V (2000) J Biol Chem 275:27021-27026

6. Lombard M, Fontecave M, Touati D, Niviere V (2000) J Biol Chem 275:115-121

7. Jenney FE Jr, Verhagen MF, Cui X, Adams MW (1999) Science 286:306-309

8. Chen L, Sharma P, Le Gall J, Mariano AM, Teixeira M, Xavier AV (1994) Eur J Biochem 226:613-618

9. Ascenso C, Rusnak F, Cabrito I, Lima MJ, Naylor S, Moura I, Moura JJG (2000) J Biol Inorg Chem 5:720-729

10. Abreu IA, Saraiva LM, Carita J, Huber H, Stetter KO, Cabelli D, Teixeira M (2000) Mol Microbiol 38:322-334

11. Moura I, Tavares P, Moura JJ, Ravi N, Huynh BH, Liu MY, LeGall J (1990) J Biol Chem 265:21596-21602

12. Tavares P, Ravi N, Moura JJ, LeGall J, Huang YH, Crouse BR, Johnson MK, Huynh BH, Moura I (1994) J Biol Chem 269:10504-10510 
13. Yeh AP, Hu Y, Jenney FE Jr, Adams MW, Rees DC (2000) Biochemistry 39:2499-2508

14. Coelho AV, Matias PM, Carrondo MA, Tavares P, Moura JJ, Moura I, Fulop V, Hajdu J, Le Gall J (1996) Protein Sci 5:1189-1191

15. Clay MD, Jenney FE Jr, Hagedoorn PL, George GN, Adams MW, Johnson MK (2002) J Am Chem Soc 124:788-805

16. Coulter E, Emerson J, Kurtz D, Cabelli D (2000) J Am Chem Soc 122:11555-11556

17. Niviere V, Lombard M, Fontecave M, Houee-Levin C (2001) FEBS Lett 497:171-173

18. Niviere V, Asso M, Weill CO, Lombard M, Guigliarelli B, Favaudon V, Houee-Levin C (2004) Biochemistry 43:808-18

19. Brumlik MJ, Voordouw G (1989) J Bacteriol 171:4996-5004

20. Coulter ED, Kurtz DM Jr (2001) Arch Biochem Biophys 394:76-86

21. Emerson JP, Coulter ED, Phillips RS, Kurtz DM Jr (2003) J Biol Chem 278:39662-39668

22. Lovenberg W, Sobel BE (1965) Proc Natl Acad Sci USA 54:193-199

23. Lovenberg W, Williams WM (1969) Biochemistry 8:141-148

24. Bachmayer H, Yasunobu KT (1967) Biochem Biophys Res Commun 26:435-440

25. Sieker LC, Stenkamp RE, LeGall J (1994) Methods Enzymol 243:203-216

26. Peisach J, Blumberg WE, Lode ET, Coon MJ (1971) J Biol Chem 246:5877-5881

27. Eidsness MK, Richie KA, Burden AE, Kurtz DM Jr, Scott RA (1997) Biochemistry 36:10406-10413

28. Eggink G, Engel H, Vriend G, Terpstra P, Witholt B (1990) J Mol Biol 212:135-142

29. Kok M, Oldenhuis R, van der Linden MP, Meulenberg $\mathrm{CH}$, Kingma J, Witholt B (1989) J Biol Chem 264:5442-5451

30. Seki S, Ikeda A, Ishimoto M (1988) J Biochem (Tokyo) 103:583-584

31. Lumppio HL, Shenvi NV, Summers AO, Voordouw G, Kurtz DM Jr (2001) J Bacteriol 183:101-108

32. Silva G, LeGall J, Xavier AV, Teixeira M, Rodrigues-Pousada C (2001) J Bacteriol 183:4413-20

33. Das A, Coulter E, Kurtz D, Ljungdahl L (2001) J Bacteriol 183:1560-1567

34. Bult CJ, White O, Olsen GJ, Zhou L, Fleischmann RD, Sutton GG, Blake JA, FitzGerald LM, Clayton RA, Gocayne JD, Kerlavage AR, Dougherty BA, Tomb JF, Adams MD, Reich CI, Overbeek R, Kirkness EF, Weinstock KG, Merrick JM, Glodek A, Scott JL, Geoghagen NS, Venter JC (1996) Science 273:1058-1073

35. Bruschi M, Le Gall J (1972) Biochim Biophys Acta 263:279282

36. Schagger H, von Jagow G (1987) Anal Biochem 166:368-379

37. Czaja C, Litwiller R, Tomlinson AJ, Naylor S, Tavares P, LeGall J, Moura JJG, Moura I, Rusnak F (1995) J Biol Chem 270:20273-20277

38. Creutz C, Sutin N (1973) Proc Natl Acad Sci USA 70:17011703
39. Fischer D, Price D (1964) Clin Chem 10:21-31

40. Bradford MM (1976) Anal Biochem 72:248-254

41. McCord JM, Fridovich I (1969) J Biol Chem 244:6049-6055

42. Eidsness MK, O'Dell SE, Kurtz DM Jr, Robson RL, Scott RA (1992) Protein Eng 5:367-371

43. Petillot Y, Forest E, Mathieu I, Meyer J, Moulis JM (1993) Biochem J 296:657-661

44. Richie KA, Teng Q, Elkin CJ, Kurtz DM Jr (1996) Protein Sci 5:883-894

45. Xiao Z, Gardner AR, Cross M, Maes EM, Czernuszewicz RS, Sola M, Wedd AG (2001) J Biol Inorg Chem 6:638-649

46. Bruschi M, Hatchikian CE, Golovleva LA, Gall JL (1977) J Bacteriol 129:30-38

47. Lovenberg W, Walker MN (1978) Methods Enzymol 53:340346

48. Le Gall J (1968) Ann Inst Pasteur (Paris) 114:109-115

49. Edelhoch H (1967) Biochemistry 6:1948-1954

50. Gill S, Von Hippel P (1989) Anal Biochem 182:319-326

51. Pace CN, Vajdos F, Fee L, Grimsley G, Gray T (1995) Protein Sci 4:2411-2423

52. Yoo SJ, Meyer J, Achim C, Peterson J, Hendrich MP, Munck E (2000) J Biol Inorg Chem 5:475-487

53. Blake PR, Park JB, Bryant FO, Aono S, Magnuson JK, Eccleston E, Howard JB, Summers MF, Adams MW (1991) Biochemistry 30:10885-10895

54. Laviron E (1979) J Electroanal Chem 101:19-28

55. Gilles de Pelichy LD, Smith ET (1999) Biochemistry 38:7874 7880

56. Correia dos Santos MM, Paes de Sousa PM, Simoes Gonçalves ML, Ascenso C, Moura I, Moura J (2001) J Electroanal Chem 501:173-179

57. LeGall J, Liu MY, Gomes CM, Braga V, Pacheco I, Regalla M, Xavier AV, Teixeira M (1998) FEBS Lett 429:295-298

58. Swartz PD, Ichiye T (1997) Biophys J 73:2733-2741

59. Ge B, Scheller FW, Lisdat F (2003) Biosens Bioelectron 18:295-302

60. Hough MA, Hasnain SS (2003) Structure (Cambridge) 11:937946

61. Klug D, Rabani J, Fridovich I (1972) J Biol Chem 247:48394842

62. Rotilio G, Bra, RC, Fielden EM (1972) Biochim Biophys Acta 268:605-609

63. Lumppio HL, Shenvi NV, Garg RP, Summers AO, Kurtz DM Jr (1997) J Bacteriol 179:4607-4615

64. Hazlett KR, Cox DL, Sikkink RA, Auchère F, Rusnak F, Radolf JD (2002) Methods Enzymol 353:140-156

65. Lambeth DO, Palmer G (1973) J Biol Chem 248:6095-6103

66. Romao CV, Liu MY, Le Gall J, Gomes CM, Braga V, Pacheco I, Xavier AV, Teixeira M (1999) Eur J Biochem 261:438-443

67. Silva G, Oliveira S, Gome CM, Pacheco I, Liu MY, Xavier AV, Teixeira M, Legal J, Rodrigues-Pousada C (1999) Eur J Biochem 259:235-243

68. Auchere F, Rusnak F (2002) J Biol Inorg Chem 7:664-667

69. Ma K, Adams MW (1999) J Bacteriol 181:5530-5533 